\title{
CHEMICAL PROFILE OF THE ROSS ICE SHELF AT LITTLE AMERICA V, ANTARGTICA
}

\author{
By C. C. Langway, Jr., M. Herron and J. H. Cragin
}

(U.S. Army Cold Regions Research and Engineering Laboratory, Hanover, New Hampshire 03755, U.S.A.)

\begin{abstract}
Measurements of the concentrations of $\mathrm{Na}^{+}, \mathrm{K}^{+}, \mathrm{Mg}^{2+}$, and $\mathrm{Ca}^{2+}$ were made on 28 samples from the $255 \mathrm{~m}$ deep ice core from Little America V. All concentrations decrease sharply with depth from the firn-ice transition at $52 \mathrm{~m}$ to somewhere between $125 \mathrm{~m}$ and $\mathrm{I} 50 \mathrm{~m}$. From $150 \mathrm{~m}$ to $250 \mathrm{~m}$ the cationic concentrations are relatively constant. This is interpreted to indicate that the ice above $125 \mathrm{~m}$ fell as snow on the Ross Ice Shelf and that ice below I50 m originated inland on Marie Byrd Land.

Résumé. Profil chimique du Ross Ice Shelf à Little America V, Antarctique. On a fait des mesures de concentrations d'ions $\mathrm{Na}^{+}, \mathrm{K}^{+}, \mathrm{Mg}^{2+}$, et $\mathrm{Ca}^{2+}$ sur 28 échantillons prélevés dans la carotte d'un forage de $255 \mathrm{~m}$ dans la glace provenant de Little America V. Toutes les concentrations décroissent rapidement avec la profondeur depuis la transition névé-glace vers $52 \mathrm{~m}$ jusqu'à un point entre 125 et 150 m. De 150 à $250 \mathrm{~m}$, les concentrations en cations sont relativement constantes. On interprète ce fait comme une indication que la glace au-dessus de $125 \mathrm{~m}$ est tombée sous forme de neige sur la calotte de Ross et que la glace en dessous de $150 \mathrm{~m}$ a son origine dans l'intérieur de la Terre Marie Byrd.

Zusammenfassung. Das chemische Profil des Ross Ice Shelf bei Little America V, Antarktis. An 28 Proben des $255 \mathrm{~m}$ langen Bohrkerns von Little America V wurden die Konzentrationen von $\mathrm{Na}^{+}, \mathrm{K}^{+}, \mathrm{Mg}^{2+}$ und $\mathrm{Ca}^{2+}$ gemessen. Alle Konzentrationen nehmen vom Firn-Eis-Übergang in $52 \mathrm{~m}$ Tiefe bis zu einer Tiefe zwischen $125 \mathrm{~m}-150 \mathrm{~m}$ schnell mit zunehmender Tiefe ab. Von $150 \mathrm{~m}-250 \mathrm{~m}$ sind die Konzentrationen der Kationen relativ konstant. Dies wird als Anzeichen dafür gedeutet, dass das Eis über $125 \mathrm{~m}$ als Schnee auf das Ross-Schelfeis fiel, während das Eis unter $150 \mathrm{~m}$ landeinwärts vom Marie Byrd Land herstammt.
\end{abstract}

\section{INTRODUCTION}

There is renewed interest in the nature and the origin of Antarctic ice shelves (for example, Ross Ice Shelf: Zumberge, r971; Amery Ice Shelf: Budd, r966; Morgan 1972). The first ice core ever to be recovered that completely penetrated a floating ice sheet (ice shelf) was obtained near the seaward edge of the Ross Ice Shelf at Little America V (lat. $78^{\circ}$ Io' S., long. $162^{\circ} 13^{\prime} \mathrm{W}$. in 1957) (Ragle and others, 1960). This core was $255 \mathrm{~m}$ long, $10 \mathrm{~cm}$ in diameter, and parts of it have been stored since recovery in cold rooms at USA CRREL at temperatures below $-20^{\circ} \mathrm{C}$.

Assuming steady-state conditions, Crary and others (1962) estimated that the bottom ice at Little America V may have originated about $340 \mathrm{~km}$ from Little America V, about $20 \mathrm{~km}$ inland from the grounding line, and that its maximum age was about 4500 years. They postulated that only the bottom $20 \mathrm{~m}$ of ice at Little America $\mathrm{V}$ originated inland in West Antarctica. Some studies of physical properties and measurements of electrolytic conductivity were made on the ice core at Little America V (Gow, I968[a], [b]). Dansgaard and others (in preparation) recently completed an investigation of the variations in the stable isotopic composition of the core. This report presents results of a study of the $\mathrm{Na}^{+}, \mathrm{K}^{+}, \mathrm{Mg}^{2+}$, and $\mathrm{Ca}^{2+}$ concentrations found in the Little America V ice core.

\section{SAMPle PREPARATION AND ANALyTical METhODS}

All laboratory work was performed in a laminar-flow clean-air station; workers wore powder-free polyethylene gloves. Core samples io to $23 \mathrm{~cm}$ long were selected, spaced over the entire depth profile below the firn-ice transition at $52 \mathrm{~m}$. Surface contaminants resulting from drilling and handling were removed from core samples by one of two procedures depending upon whether or not drilling fluid was used during the coring operation. The core above $250 \mathrm{~m}$ was obtained in a "dry-hole" (i.e. without the use of drilling fluids), and samples were prepared for chemical analysis by holding them with stainless steel tongs and rinsing with 
doubly-distilled de-ionized water (DDW). Approximately I $200 \mathrm{ml}$ of DDW was used per $500 \mathrm{~g}$ of sample. Samples below $250 \mathrm{~m}$ were exposed to drilling fluid $(88 \%$ diesel fuel and I $2 \%$ trichloroethylene) and were cleaned by alternate rinsings with electronic grade acetone and distilled de-ionized water until the odor of drilling fluid could no longer be detected. The core was then rinsed with DDW as described above. The effectiveness of both cleaning procedures was verified (Herron and others, in preparation) by the constancy of ionic concentrations observed in melt water collected sequentially as progressive outer layers of core are removed by melting. For example, the sodium concentration of the outer $20 \%$ of a "dry-hole" sample was $185 \mu \mathrm{g} / \mathrm{l}$, while the remaining five aliquots had an average sodium concentration of $24.4 \pm \mathrm{r} .8 \mu \mathrm{g} / \mathrm{l}$. Similarly, the outer $30 \%$ of a core sample exposed to drilling fluid contained an order of magnitude higher sodium concentration than the $29.0 \pm 0.7 \mu \mathrm{g} / \mathrm{l}$ average of the inner aliquots.

Both groups of solid cleaned samples were then melted in pre-cleaned polyethylene containers in a microwave oven and aliquots were taken for analysis. Measurements were made directly on the melt water using atomic absorption. Samples and standards were analyzed in triplicate with average standard deviations in $\mu \mathrm{g} / \mathrm{l}$ of: $\mathrm{Na}^{+}, \mathrm{I} .2 ; \mathrm{K}+, 0.6 ; \mathrm{Mg}^{2+}, 0.3$; and $\mathrm{Ca}^{2+}, 0.7$.
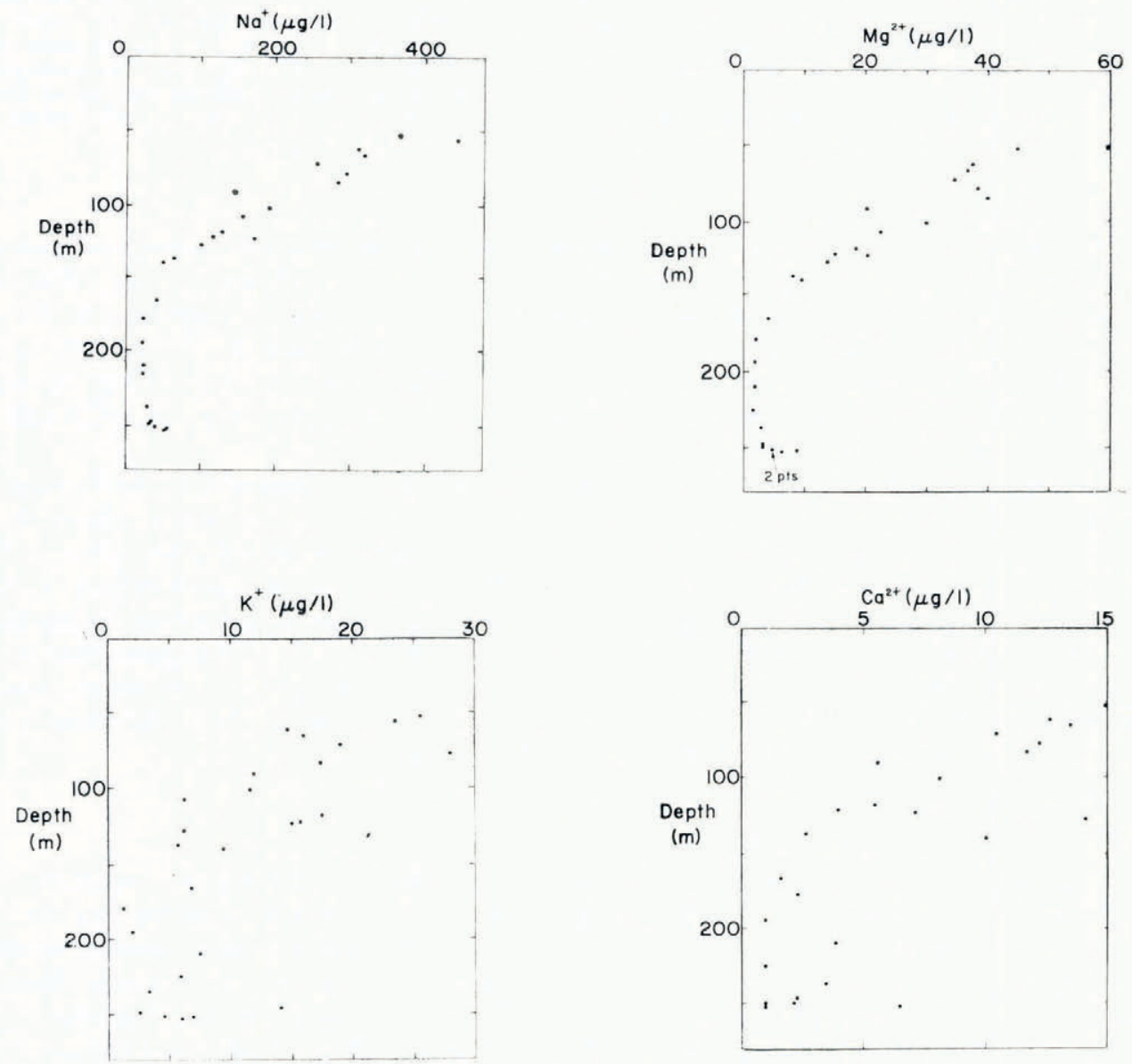

Fig. I. Concentration profile of $\mathrm{Na}^{+}, \mathrm{Mg}^{2+}, \mathrm{K}^{+}$and $\mathrm{Ca}^{2+}$ in the Little America $\mathrm{V}$ ice core. 


\section{RESUlts AND Discussion}

The results of the measurements are presented in Figure I. Table I lists averages of these data and the $\mathrm{Na} / \mathrm{K}, \mathrm{Na} / \mathrm{Mg}$ and $\mathrm{Na} / \mathrm{Ca}$ ratios. All cationic concentrations decrease sharply from a depth of $52 \mathrm{~m}$ to somewhere between $125 \mathrm{~m}$ and $\mathrm{I} 50 \mathrm{~m}$. From approximately $150 \mathrm{~m}$ to $250 \mathrm{~m}$, the cationic concentrations appear relatively constant. A slight increase in all of the measured constituents appears below $250 \mathrm{~m}$.

Table I. Average cationic concentrations in ice core samples from Little America V and "Byrd" station, Antarctica

\begin{tabular}{|c|c|c|c|c|c|c|c|}
\hline $\begin{array}{c}\text { Depth } \\
\mathrm{m}\end{array}$ & $\begin{array}{l}\mathcal{N} a^{+} \\
\mu \mathrm{g} / 1\end{array}$ & $\begin{array}{c}K^{+} \\
\mu \mathrm{g} / 1\end{array}$ & $\begin{array}{l}\mathrm{Mg}^{2+} \\
\mu \mathrm{g} / 1\end{array}$ & $\begin{array}{l}C a^{2+} \\
\mu \mathrm{g} / \mathrm{l}\end{array}$ & $\mathrm{Na} / \mathrm{K}$ & $\mathcal{N a} / \mathrm{Mg}$ & $\mathrm{Na} / \mathrm{Ca}$ \\
\hline $\begin{array}{l}5^{2-} 84(7)^{*} \\
90-123(6)^{*}\end{array}$ & $325 \pm 62 \ddagger$ & $2 \mathrm{I} \pm 6$ & $4^{2} \pm 9$ & $13 \pm 2$ & $16 \pm 4$ & $7.8 \pm 0.6$ & $\begin{array}{l}24 \pm 1 \\
25 \pm 3\end{array}$ \\
\hline $\begin{array}{r}90-123(6) \\
126-150(3)\end{array}$ & $\begin{array}{r}152 \pm 28 \\
78+20\end{array}$ & $\begin{array}{r}13 \pm 4 \\
7 \pm 2\end{array}$ & $2 \mathrm{I} \pm 5$ & $6 \pm 2$ & $13 \pm 7$ & $7 \cdot 3 \pm 0.8$ & $\begin{array}{l}25 \pm 3 \\
13+10\end{array}$ \\
\hline $\begin{array}{l}\text { I } 26-150(3) \\
\text { I } 50-250(8)\end{array}$ & $\begin{array}{l}78 \pm 20 \\
29 \pm 7\end{array}$ & $\begin{array}{c}7 \pm 2 \\
5.4 \pm 4.1\end{array}$ & $\begin{array}{c}10 \pm 3 \\
2.6 \pm 0.9\end{array}$ & $\begin{array}{c}9 \pm 6 \\
2.2 \pm 1.0\end{array}$ & $\begin{array}{r}12 \pm 4 \\
9 \pm 6\end{array}$ & $\begin{array}{r}7.6 \pm 0.4 \\
11.6 \pm 1.7\end{array}$ & $\begin{array}{l}13 \pm 10 \\
13 \pm 7\end{array}$ \\
\hline $250-255(4)$ & $48 \pm 8$ & $5 \pm 2$ & $6.2 \pm 1.9$ & $2.6 \pm 2.7$ & $10 \pm 3$ & $8 \pm 1$ & $8 \pm 2$ \\
\hline Byrd station core average $\dagger$ & $28 \pm$ I I & $3.5 \pm 1.9$ & $2.4 \pm 1.0$ & $3.2 \pm 2.5$ & $9 \cdot 3 \pm 2.4$ & $12 \pm 3$ & $5.6 \pm 2$ \\
\hline Sea-water & & & & & 27 & 8 & 28 \\
\hline
\end{tabular}

* Number in parentheses is the number of samples analyzed for $\mathrm{Na}^{+}, \mathrm{K}^{+}$and $\mathrm{Mg}^{2+}$ over the stated depth interval. For $\mathrm{Ca}^{2+}$ one less sample was analyzed in each of the depth intervals $52-84,90-123$, and $250-255 \mathrm{~m}$, resulting in a total of 25 samples.

$\dagger$ Average of five samples deposited between I 800 and 2500 B.P. from the Byrd station deep ice core (Cragin and others, in press).

$\ddagger$ Deviations represent a measure of dispersion of the concentrations for the number of samples measured and are not an indication of precision.

Since deposited snow follows the "law of superposition" (i.e. younger layers overlie older layers), it is evident that the deeper shelf ice is older than the upper shelf ice and originated further up-stream along a flow-line. The differences in cationic concentrations between the ice above $125 \mathrm{~m}$ and that below $150 \mathrm{~m}$ indicate that the upper ice originated on the shelf itself and that the lower ice originated inland from the grounding line in a different environmental regime. The reported flow-line of ice from West Antarctica to Little America V runs parallel to the West Antarctic coast until it passes the grounding line and then moves toward the seaward edge of the shelf (Hughes, 1973). Thus, the lower ice could have been deposited at a rather constant distance from the coast; this explains the uniform composition of the core from $\mathrm{I} 50 \mathrm{~m}$ to $250 \mathrm{~m}$.

As shown in Table I, concentration levels and ratios in the lower portion of the core are quite close to those found in recent deposits from the "Byrd" station, West Antarctica area (Cragin and others, in preparation) which is more than $700 \mathrm{~km}$ from Little America V. This suggests that the lower ice in the Little America V core originated in an environmental regime similar to that in West Antarctica. The ratios of $\mathrm{Na} / \mathrm{K}, \mathrm{Na} / \mathrm{Mg}$ and $\mathrm{Na} / \mathrm{Ca}$ for the upper portion of the Little America $\mathrm{V}$ core approach those of sea-water, reflecting the proximity of the open Ross Sea. The $\mathrm{Na} / \mathrm{K}$ and $\mathrm{Na} / \mathrm{Ca}$ ratios decrease with depth; this may indicate a geochemical enrichment of $\mathrm{K}^{+}$and $\mathrm{Ca}^{2+}$ relative to $\mathrm{Na}^{+}$that becomes more pronounced in deposits greater distances from the coast (Chesselet and others, 1972; Boutron and others, 1972). The low silicon concentration $(0.8 \mu \mathrm{g} / \mathrm{l})$ found in West Antarctica (Murozumi and others, 1969) suggests that the contribution of terrestrial dust to Marie Byrd Land is negligible.

The above interpretation is in accord with a possible interpretation of the profile of the stable isotopic composition of the core (Dansgaard and others, in preparation). Also, Gow (1970) found an abrupt change in ice texture and fabric in the core at about $150 \mathrm{~m}$ which he suggested may be due to a transition from shelf- to inland-derived ice. The slight apparent 
increase below $250 \mathrm{~m}$ in all constituents measured cannot be entirely due to diffusion of ions from the sea-water below. In addition, the concentration levels in the bottom $5 \mathrm{~m}$ of the core are too low to indicate sea-water accretion and, in fact, physical and temperature gradient considerations indicate that appreciable melting of the bottom of the ice occurs at Little America V (Crary and others, I962). Furthermore, stable oxygen isotopic measurements confirm that the core is composed entirely of glacial ice (Dansgaard and others, in preparation).

In the absence of supporting chemical data along the proposed flow-line, another interpretation of the data must be considered. Concentrations of sea-salt constituents in precipitation generally decrease with increasing distance from the coast until a stable concentration plateau is reached (Junge, I 1963 ). In general, the greater the distance of this plateau from the coast the lower the plateau concentration. Such a plateau was found to exist at distances of $600 \mathrm{~km}$ to $900 \mathrm{~km}$ from the coast in East Antarctica, with average plateau sodium concentrations of $23 \mu \mathrm{g} / \mathrm{l}$ (Boutron and others, 1972). This compares favourably with the average sodium concentration of $27 \mu \mathrm{g} / \mathrm{l}$ in the section of the Little America V core approximately from I $50 \mathrm{~m}$ to $250 \mathrm{~m}$. No corresponding traverse data exist for West Antarctica; but, if a similar phenomenon exists there, the relative constancy of the concentrations in the portion of the core from $150 \mathrm{~m}$ to $250 \mathrm{~m}$ suggests that this mass of ice may have originated more than $600 \mathrm{~km}$ inland from Little America V.

\section{Conclusions}

Our results suggest that more than the lower $20 \mathrm{~m}$ of the Ross Ice Shelf at Little America V must have originated inland from the grounding line. We are led to believe that flow conditions in West Antarctica have not existed in a steady state for the last several thousand years. If the lower ice originated $600 \mathrm{~km}$ from Little America V instead of the calculated $340 \mathrm{~km}$ (Crary and others, 1962), flow rates may have been much higher in the recent past than at present and the age of the bottom ice may be much less than the calculated 4500 years. Johnsen and others (1972) reported an apparent decrease in surface altitude at Byrd Station with a greatly negative mass budget lasting from 4000 B.P. to 2500 B.P. The accompanying increased ice flow rates would probably bring ice from further inland to little America V. A more definitive analysis of the recent history of the Ross Ice Shelf depends upon additional cores and surface samples from various geographical areas of West Antarctica.

\section{Acknowledgements}

Financial support was provided by the National Science Foundation under grants AG-2 I 2 and AG-394. We thank G. Klouda of USA CRREL who performed some of the chemical analyses and S. J. Johnsen of the University of Copenhagen who kindly reviewed the manuscript.

MS. received 22 April 1974 and in revised form 23 May 1974

\section{REFERENCES}

Boutron, D., and others. 1972. Chemistry of polar snows. Estimation of rates of deposition in Antarctica, by D. Boutron, M. Echevin and C. Lorius. Geochimica et Cosmochimica Acta, Vol. 36, No. 9, p. 1029-4I.

Budd, W. F. 1966. The dynamics of the Amery Ice Shelf. Fournal of Glaciology, Vol. 6, No. 45, p. $335-58$.

Chesselet, R., and others. I972. Variations in ionic ratios between reference sea water and marine aerosols, by R. Chesselet, J. Morelli and P. Buat-Menard. Journal of Geophysical Research, Vol. 77, No. 27, p. 51 16-31.

Cragin, J. H., and others. In press. Interhemispheric comparison of the composition of atmospheric precipitation during the late Cenozoic era, by J. H. Cragin, M. M. Herron, C. C. Langway, Jr., and G. Klouda. [Presented at the SCOR/SCAR Polar Oceans Conference, Montreal, Canada, 5-1 I May r974.] 
Crary, A. P., and others. 1962. Glaciological regime of the Ross Ice Shelf, by A. P. Crary, E. S. Robinson, H. F. Bennett and W. W. Boyd, Jr. Journal of Geophysical Research, Vol. 67, No. 7, p. $2791-807$.

Gow, A. J. I968[a]. Deep core studies of the accumulation and densification of snow at Byrd station and Little America V, Antarctica. U.S. Cold Regions Research and Engineering Laboratory. Research Report 197.

Gow, A. J. I $968[\mathrm{~b}]$. Electrolytic conductivity of snow and glacier ice from Antarctica and Greenland. Fournal of Geophysical Research, Vol. 73, No. 12, p. 3643-49.

Gow, A. J. 1970. Deep core studies of the crystal structure and fabrics of Antarctic glacier ice. U.S. Cold Regions Research and Engineering Laboratory. Research Report 282.

Hughes, T. J. 1973. Is the West Antarctic ice sheet disintegrating? Journal of Geophysical Research, Vol. 78, No. 33 , p. 7884-910.

Johnsen, S. J., and others. 1972. Oxygen isotope profiles through the Antarctic and Greenland ice sheets, [by] S. J. Johnsen, W. Dansgaard, H. B. Clausen, C. C. Langway, Jr. Nature, Vol. 235, No. 5339, p. 429-34.

Junge, C. E. 1963 . Air chemistry and radioactivity. New York, Academic Press.

Morgan, V. I. 1972. Oxygen isotope evidence for bottom freezing on the Amery Ice Shelf. Nature, Vol. 238, No. 5364 , p. $393-94$.

Murozumi, M., and others. I969. Chemical concentrations of pollutant lead aerosols, terrestrial dusts and sea salts in Greenland and Antarctic snow strata, [by] M. Murozumi, T. J. Chow and C. Patterson. Geochimica et Cosmochimica Acta, Vol. 33, No. 10, p. 1247-94.

Ragle, R. H., and others. I960. Deep core drilling in the Ross Ice Shelf, Little America V, Antarctica, by R. H. Ragle, B. L. Hansen, A. J. Gow, and R. W. Patenaude. U.S. Snow, Ice and Permafrost Research Establishment. Technical Report 70.

Zumberge, J. H. I971. "Ross Ice Shelf Project." Antarctic Fournal of the United States, Vol. 6, No. 6, p. 258-63. 